\title{
Music Intervention for Perceived Stress Among English Education Students
}

\author{
Edith N. Nwokenna ${ }^{1}$, Nneka Nwosu ${ }^{2}$, Uche L. Igbokwe ${ }^{1}$, Vera Victor-Aigbodion ${ }^{2}$, \\ Ogechi Nnamani ${ }^{2} \&$ Bartholomew C. Nwefuru ${ }^{2}$ \\ ${ }^{1}$ Department of Arts Education, University of Nigeria Nsukka, Enugu State, Nigeria \\ ${ }^{2}$ Department of Educational Foundations, Nigeria Nsukka, Enugu State, Nigeria \\ Correspondence: Nneka Nwosu, Department of Educational Foundations, Nigeria Nsukka, Enugu State, Nigeria.
}

Received: May 12, 2019 Accepted: June 15, 2019 Online Published: June 17, 2019

doi:10.5539/gjhs.v11n8p23 URL: https://doi.org/10.5539/gjhs.v11n8p23

\begin{abstract}
Objective/Background: This research objective was to examine the effect of music intervention on perceived stress among English education students.

Method: Out of 200 students surveyed, 56 English education undergraduate students who were having high-stress level participated in the study. The 56 eligible participants were randomized into one of two study groups: music intervention group $(\mathrm{n}=28)$ and waitlist control group $(\mathrm{n}=28)$ using computer-generated random numbers. All participants completed baseline evaluation and posttests at 4, 8 and 12 weeks. Participants completed the Perceived Stress Scale. The statistical tool used for data analysis was within and between ANOVA.

Result: There was a significant difference in perceived stress between English education students in the music intervention group and waitlisted group. Significant reduction in the level of perceived stress among English education students was observed in the music intervention group, but the waitlisted group demonstrated no significant reduction in their stress score both at 4,8 and 12 weeks posttests respectively.

Conclusion: Music intervention is an effective means of handling stress among English education students. Further studies are required to investigate the role of music therapy in burnout reduction among English education students in Nigerian universities.
\end{abstract}

Keywords: music intervention, perceived stress, therapist, English education students

\section{Introduction}

Stress is the physiological and psychological response to a situation that affects an individual's overall wellbeing (Yusuf, Olufunke, \& Valentine, 2015). Selye (1978) argued that stress is an internal or external event capable of threatening to upset individual's balanced state of living. Nowadays, the situation faced by students can produce stress. According to Jalaluddin et al. (2009), students are being faced with a lot of stress in learning the second language which could be due to their learning behaviour, classroom interaction, unavailability of qualified teachers, and lack of self-confidence. Akinbode (2006) observed that English education students find the learning of English stressful due to the differences in the second language learning structure, rules of grammar, language transfer, faulty use of rules, inadequate instructional materials for teaching and learning among others when compared with the mother tongue. Rivers (1988) opined that stress is being noticed among English education students as a result of their inability to reconcile the differences between rules of grammar in the second language and their native language. Wang (1999) stated that failure and frustration resulting from poor performance among English education students can result in a high level of perceived stress among students. Jayashree (1989) stated that teachers' inability to breathe hope into their students in teaching and learning of English makes it stressful for students. Young (1996) revealed that students get stressed and confused in the area of similarities between native and second language. Wallace, Boynton and Lytle (2017) attributed the stress of students to frequent exposure to an assignment, test, presentations, regular examinations, and other worries, such as financial and social needs.

Horn (2007) stated that music is a form of language, using timbre, pitch, tones and rhythm as a general language. Stansell (2005) noted that the musical method involves having fun with language and letting words come easily to enforce social interaction and group discussion. Weisskoff (1981) stated that music influences learning in core subjects and enables learners to attain the main objective of learning. Mora (2000) asserted that music and 
language should be used in the teaching of English as a second Language regularly. Accordingly, Horn (2007) opined that music intervention enables individuals to freely learn from each other using musical approaches such as musical performance, improvisation, vocalization, movement and listening. Jalongo and Bromley (1984) asserted that music intervention improves the learning of English language especially in the area of grammar, spelling, reading, and writing, speaking and listening. Lalas and Lee (2002) found that music therapy is a strong mechanism through which both native and foreign language can be communicated better. McCarthey (1985) reported that music helps English learners to positively improve in listening, reading, writing, vocabulary and grammar. Pelliteri (2000) found that music and music therapy has positive impacts on music and non-music students. Strydom (2011) reported that music and music therapy is effective for improving second language learning among students of various capacities. Schwantes (2009) found that effective use of music enhances the learning of languages. The present study determined the effect of music intervention on perceived stress among English Education students in Nigeria

\section{Methods}

The study used a group randomized controlled trial design. The study protocol was approved by the Faculty of Education Research Ethics Committee, University of Nigeria Nsukka. The study was carried out in South-East, Nigeria. The study participants were English Education students of federal institutions who had not received any treatment on stress. Fifty-six (56) eligible participants aged 19 years and above, with perceived stress over a year and accept to provide informed consent were selected for the study. A participant was excluded if he/she has no perceived stress symptoms for up to a semester and if he/she is already engaged in another therapeutic exercise. The 56 eligible participants were randomized into one of two study groups: music intervention group $(\mathrm{n}=28)$ and waitlist control group $(\mathrm{n}=28)$ using computer-generated random numbers. Participants completed the Perceived Stress Scale (Cohen et al., 1988) at baseline, 4, 8, and 12 weeks of music intervention. The PSS comprises of 10 items on a 4point scale. The study protocol was described to all participants, and informed consent forms were completed after a clear explanation of the research goal. After completing the baseline evaluation, the participants were exposed to 12-weeks music intervention sessions. The study participants were asked to attend the group intervention session twice weekly. Each music session lasted for 90 minutes. The music intervention activities included singing, dancing exercise, reading among others (Ezegbe et al., 2018). The study participants were also given self-help manuals for home training which complemented the in-session music intervention. All waitlisted participants were scheduled to start the music intervention sessions immediately the music intervention group participants have had their last music intervention session and assessment. Participants in the waitlist group had casual meetings and discussions about perceived stress during the waiting period. The statistical tool used for data analysis was ANOVA Data was normally distributed and there were no missing data. All analyses were conducted using SPSS computer software, version 22.0 (IBM Corp. NY, United States). All p-values $\leq 0.05$ were considered to be significant.

\section{Result}

The study participants were twenty-eight (28) in the treatment group (12 males, 16 females) and twenty-eight (28) waitlisted control group (10 males, 18 females). Table 1 shows the mean stress of each study group according to period of assessment. 
Table 1. Descriptive statistics

\begin{tabular}{llllll}
\hline Group & & Baseline & Week4 & Week8 & Week12 \\
\hline Music Intervention Group & M & 31.9643 & 13.6429 & 8.1786 & 8.2143 \\
& N & 28 & 28 & 28 & 28 \\
& SD & 3.10891 & 4.84741 & 3.37807 & 3.32618 \\
& SEM & .58753 & .91607 & .63840 & .62859 \\
\hline Music Non-intervention Group & Mean & 32.2500 & 32.2500 & 31.1786 & 31.5714 \\
& N & 28 & 28 & 28 & 28 \\
& SD & 3.21599 & 3.21599 & 7.92116 & 2.71387 \\
& SEM & .60777 & .60777 & 1.49696 & .51287 \\
\hline Total & M & 32.1071 & 22.9464 & 19.6786 & 19.8929 \\
& N & 56 & 56 & 56 & 56 \\
& SD & 3.13733 & 10.23438 & 13.07893 & 12.16206 \\
& SEM & .41924 & 1.36763 & 1.74775 & 1.62522 \\
\hline
\end{tabular}

$\mathrm{M}=$ Mean, $\mathrm{N}=$ Number of Respondents, $\mathrm{SD}=$ Standard Deviation, $\mathrm{SEM}=$ Standard Error Mean.

Table 2. ANOVA Table

\begin{tabular}{|c|c|c|c|c|c|c|c|c|}
\hline & & & Sum of Squares & df & Mean Square & $\mathbf{F}$ & Sig & Eta Squared \\
\hline \multirow{3}{*}{$\begin{array}{l}\text { Baseline * } \\
\text { Group }\end{array}$} & B/W Groups & (Combined) & 1.143 & 1 & 1.143 & & & \\
\hline & Within Groups & & 540.214 & 54 & 10.004 & .114 & .737 & .002 \\
\hline & Total & & 541.357 & 55 & & & & \\
\hline \multirow{3}{*}{$\begin{array}{l}\text { Week4 * } \\
\text { Group }\end{array}$} & B/W Groups & (Combined) & 4847.161 & 1 & 4847.161 & & & \\
\hline & Within Groups & & 913.679 & 54 & 16.920 & 286.476 & .000 & .841 \\
\hline & Total & & 5760.839 & 55 & & & & \\
\hline \multirow{3}{*}{$\begin{array}{l}\text { Week8 * } \\
\text { Group }\end{array}$} & B/W Groups & (Combined) & 7406.000 & 1 & 7406.000 & & & \\
\hline & Within Groups & & 2002.214 & 54 & 37.078 & 199.741 & .000 & .787 \\
\hline & Total & & 9408.214 & 55 & & & & \\
\hline \multirow{3}{*}{$\begin{array}{l}\text { Week12 * } \\
\text { Group }\end{array}$} & B/W Groups & (Combined) & 7637.786 & 1 & 7637.786 & & & \\
\hline & Within Groups & & 497.571 & 54 & 9.214 & 828.907 & .000 & .939 \\
\hline & Total & & 8135.357 & 55 & & & & \\
\hline
\end{tabular}

As shown in Table 2 of the investigation, there was no significant difference in the baseline assessment for perceived stress between the music intervention group and the music non-intervention group, $F(1,54)=.114, P$ $=.737$. The participants' assessment at $4^{\text {th }}$ week showed a significant decrease of perceived stress among English education university students in the music intervention group compared with those in the music non-intervention group, $F(1,54)=284.476, P=.000$.

Nevertheless, perceived stress among English education students at $8^{\text {th }}$ week showed a significant decrease in the music intervention group compared with those in non-music intervention group $F(1,54)=199.741, P=.000, \mathrm{n}^{2}$ $=.787$. And at the $12^{\text {th }}$-week assessment of participants showed a more significant decrease in perceived stress among English education students in the music intervention group compared with those in non-music intervention group $F(1,54)=828.907), P=.000$.

\section{Discussion}

The study investigated music intervention for perceived stress reduction among English education students in Nigeria. The study found that music intervention reduces perceived stress among English education students. 
Ezegbe et al. (2018) reported that music intervention provides a positive reduction in the level of psychological distress among individuals. Sutton and De Baker (2009) reported that music intervention is an effective strategy in handling individual emotional state in reducing tension and distress. Lesiuk (2008) found that music intervention enables a stressed person (s) to relax, think among promotes the individual's wellbeing. Smith, Casey, Johnson, Gwede, Riggin (2001) found that music intervention is an effective measure of reducing stress among learners of both native and second language. Clark, Isaacks-Downton, Wells, Redlin-Frazier, Eck, Hepworth, Chakravarthy (2006) reported that music intervention reduces stress among students and offers them comfort in learning vocabulary, grammar, reading and writing among others. Beaulieu-Boire, Bourque, Chagnon, Chouinard, Gallo-Payet, Lesur (2013) reported that music intervention is effective for reducing stress among second language learners of various capacities. Schwantes (2009) found that effective use of music intervention enhances the learning of languages without stress. Willenswaard, Lynn, McNeill, McQueen, Dennis, Lobel and Alderdice. (2016) reported that emotional issues of any kind are easily resolved through music intervention. Langer (1957) reported that music is the language of emotions and therefore performs different functions in individualized and conventional life stress of a wedding, feasts, funerals, war among others. Aguirre, Bustinza and Garvich (2016) found that students are induced to interact freely without stress in class activities when songs are initiated. O'Callaghan, McDermott, Michael, Daveson, Hudson and Zalcberg (2014) found that life stress among adults is dozed off with music intervention. Joyce (2011) reported that students' vocabulary is built better with music intervention as they learn with little or no stress. Thompson (2009) found that individuals perceived stress can be properly managed with music intervention since music intervention balances psychophysical cues and expectancy mechanism of individuals. Hyde et al. (2009) reported that music intervention improves activation and development of neuronal structures of cortex, amygdala, hippocampus, and hypothalamus and improves plasticity and neurogenesis among others. Lemmer (2008) found that music intervention can improve or reduce stress since it has the capacity of boasting and reducing heart rate and blood pressure of an individual. Iwanaga et al. (2005) reported that music intervention is a means through which stressors regain relaxation. Brennan and Charnetski (2000) found that music intervention is the killer of markers of stress. Wachi et al. (2007) reported that music intervention promotes the modulation of the natural killer-cell activity and the level of cytokine IL-10, which are stress markers and stabilize mood. Nelson et al. (2008) found that music intervention may restore some of the distorted homeostasis observed in patients; decrease pain and the need for sedation. Rosova (2007) found that music intervention helps learners to retain information without stress than other learning techniques. Sigurðardóttir (2012) reported that music intervention enables students to learn and pronounce English words correctly with or without stress.

\section{Conclusion}

This study investigated music intervention for perceived stress reduction among English education students. The music intervention brought about a positive reduction in perceived stress of the recipients compared to participants in a waitlisted control group. Thus, we concluded that music intervention is helpful to students toward overcoming perceived stress. To that end, further studies are needed to continuously determine how students can handle their perceived stress in both public and private universities in Nigeria, using music intervention.

\section{Competing Interests Statement}

The authors declare that there are no competing or potential conflicts of interest.

\section{References}

Aguirre, D., Bustinza, D., \& Garvich, M. (2016). Influence of Songs in Primary School Students' Motivation for Learning English in Lima, Peru. English Language Teaching, 9(2), 178-191. https://doi.org/10.5539/elt.v9n2p178

Akinbode, J. O. (2006). Reasons for Mass Failure in Senior Secondary Certificate Examinations English Language in Nigeria. Nigerian Journal of Professional Teachers, 1(3).

Beaulieu-Boire, G., Bourque, S., Chagnon, F., Chouinard, L., Gallo-Payet, N., \& Lesur, O. (2013). Music and biological stress dampening in mechanically-ventilated patients at the intensive care unit ward-a prospective interventional randomized crossover trial. Journal of Critical Care, 28(4), 442-450. https://doi.org/10.1016/j.jcrc.2013.01.007

Brennan, F. X., \& Charnetski, C. J. (2000). Stress and immune system function in a newspaper's newsroom. Psychological Reports, 87(1), 218-222. https://doi.org/10.2466/pr0.2000.87.1.218

Clark, M., Isaacks-Downton, G., Wells, N., Redlin-Frazier, S., Eck, C., Hepworth, J., \& Chakravarthy, B. (2006). Use of preferred music to reduce emotional distress and symptom activity during radiation therapy. Journal 
Music Therapy, 43(3), 247-265. https://doi.org/10.1093/jmt/43.3.247

Defaz, R. (2011). Capacitación y aplicación de un manual de canciones de recreación en el área de lenguajeycomunicación, para el proceso de enseñanza y aprendizaje de los niños del segundoaño de educaciónbásicade la escuela fiscal mixtapichincha del cantónSaquisilí del barrio salacalledurante el período 2009-2010. UnidadAcadémica de Ciencias Administrativas y Humanisticas, UTC, Latacunga., 52-63.

Horn, C. A. (2007). English second language learners: using music to enhance the listening abilities of grade ones. Masters thesis. Unisa. Retrieved February 5, 2010, from http://etd.unisa.ac.za/ETDdb/theses/available/etd09212007.133117/unrestricted/dissertation.pdf

Hyde, K. L., Lerch, J., Norton, A., Forgeard, M., Winner, E., Evans, A. C., et al. (2009). Musical training shapes structural brain development. Journal of Neuroscience, 29, 3019-3025. https://doi.org/10.1523/JNEUROSCI.5118-08.2009

Iwanaga, M., Kobayashi, A., \& Kawasaki, C. (2005).Heart rate variability with repetitive exposure to music.Biological Psychiatry, 70, 61-66.https://doi.org/10.1016/j.biopsycho.2004.11.015

Jalaluddin, N. H., Awal, N. M., \& Bakar, K. A. (2009). Linguistics and environment in English language learning: towards the development of quality human capital. European Journal of Social Sciences, 9(4), 627-642.

Jayashree. (1989). Identification of the difficulties in teaching and learning English as a second language among the high school students. In Buch, M.B. (Ed.), Fifth Survey of Educational Research (1988-1992), 2, 752, New Delhi: NCERT.

Joyce, M. (2011).Vocabulary acquisition with kindergarten children using song picture book (Doctoral dissertation). Retrieved

from https://repository.library.northeastern.edu/downloads/neu:2579?datastream_id=content

Lalas, J., \& Lee, S. (2002). Language, Literacy,and Academic Development for English language Learners. Pearson Educational Publishing.

Langer, S. K. (1957). Philosophy in a new key. Massachusetts: Harvard University Press.

Lemmer, B. (2008). Effects of music composed by Mozart and Ligeti on blood pressure and heart rate circadian rhythms in normotensive and hypertensive rats. Chronobiology International, 25, 971-986.https://doi.org/10.1080/07420520802539415

Lesiuk, T. (2008). The effect of preferred music listening on stress levels of air traffic controllers. Arts in Psychotherapy, 35,1-10.https://doi.org/10.1016/j.aip.2007.07.003

Mora, C. F. (2000). Foreign language acquisition and melody singing. ELT Journal, 54(2), 146-152. https://doi.org/10.1093/elt/54.2.146

Nelson, A., Hartl, W., Jauch, K. W., Fricchione, G. L., Benson, H., Warshaw, A. L., et al. (2008). The impact of music on hypermetabolism in critical illness.Current Opinion in Clinical Nutrition and Metabolic Care, 11, 790-794. https://doi.org/10.1097/MCO.0b013e328314dd01

O'Callaghan, C., McDermott, F., Michael, N., Daveson, B., Hudson, P., \& Zalcberg, J. (2014). A quiet still voice that just touches: music's relevance for adults living with life-threatening cancer diagnoses. Support Care Cancer, 22, 1037-1047. https://doi.org/10.1007/s00520-013-2059-1

Pelliteri, J. (2000). The Consultant's Corner: music therapy in the special education setting. Journal of Educational and Psychological Consultation, 11(3-4), 379-391. https://doi.org/10.1207/S1532768XJEPC113\&4_06

Rivers, W. M. (1988). The Psychologist and the Foreign Language Teacher. Chicago: Michigan University Press.

Rosová, V. (2007). The Use of Music in Teaching English. Masaryk University, 1-86. Retrieved from http://is.muni.cz/th/84318/pedf_m/diploma_thesis_1.pdf

Schwantes, M. (2009). The use of music therapy with children who speak English as a second language: an exploratory study. Music Therapy Perspectives, 27(2), 80-87. https://doi.org/10.1093/mtp/27.2.80

Selye, H. A. (1978). Stress without Distress. Philadelphia, PA: Lipincott.

Sigurðardóttir, D. (2012). Language Learning through Music. MenntavisindasviðHáskólaÍslands, 1-33. Retrieved from

http://skemman.is/stream/get/1946/12591/25761/1/B.Ed._Thesis._Language_learning_through_music._Dr \%C3\%ADfa_Sigur\%C3\%B0ard\%C3\%B3ttir.pdf 
Smith, M., Casey, L., Johnson, D., Gwede, C., \& Riggin, O. (2001). Music as a therapeutic intervention for anxiety in patients receiving radiation therapy. Oncol Nurs Forum, 28(5), 855-862.

Stansell, J. W. (2005). The Use of Music for Learning Languages: A Review of the Literature. University of Illinois at Urbana-Champaign.Retrieved May 27, 2013, from http://mste.illinois.edu/courses/ci407su02/

Strydom, C. (2011). Two class teachers experiences of group music therapy for intellectually impaired learners in Namibia (Unpublished Masters Dissertation. Pretoria: University of Pretoria).

Sutton, J., \& De Baker, J. (2009). Music, trauma and silence: The state of art. Arts in Psychotherapy, 36, 81-82. https://doi.org/10.1016/j.aip.2009.01.009

Thompson, W. F. (2009). Music, thought, and feeling. New York: Oxford University Press.

Wachi, M., Koyama, M., Utsuyama, M., Bittman, B. B., Kitagawa, M., \&Hirokawa, K. (2007). Recreational music-making modulates natural killer cell activity, cytokines, and mood states in corporate employees. Medicine Science Monitor, 13, CR57-CR70.

Wang, W. (1999). Age and second language acquisition in adulthood: The learning experiences and perceptions of women immigrants. TESL Canada Journal/La Revue TESL du Canada, 16(2), 1-19. https://doi.org/10.18806/tesl.v16i2.715

Weisskoff, R. S. (1981). The relationship of pop/rock music to children's task performance and continuing motivation in language arts instruction (Unpublished doctoral dissertation, University of Connecticut, Hartford, CT).

Willenswaard, K. C., Lynn, F. McNeill, J., McQueen, K., Dennis, C., Lobel, M., \& Alderdice, F. (2016). Music interventions to reduce stress and anxiety in pregnancy: A systematic review and meta-analysis. $B M C$ Psychiatry, 17, 271. https://doi.org/10.1186/s12888-017-1432-x

Yusuf, F. A., Olufunke, Y. R., \& Valentine, M. D. (2015). Causes and Impact of Stress on Teachers' Productivity as Expressed by Primary School Teachers in Nigeria. Creative Education, 6, 1937-1942. https://doi.org/10.4236/ce.2015.618199

\section{Copyrights}

Copyright for this article is retained by the author(s), with first publication rights granted to the journal.

This is an open-access article distributed under the terms and conditions of the Creative Commons Attribution license (http://creativecommons.org/licenses/by/4.0/). 